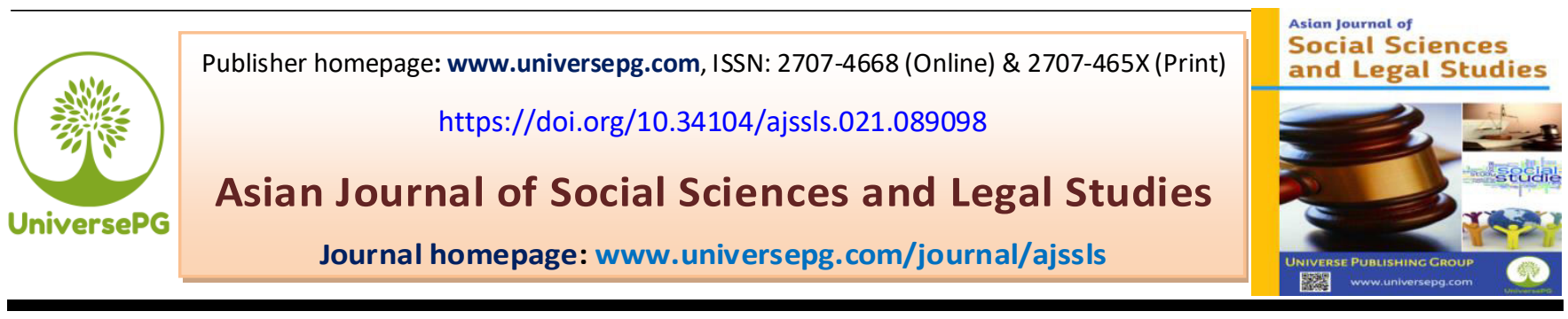

\title{
Determinants of Early Marriage among the Women: A Study on Khulna District
}

\author{
Md. Jahidul Islam ${ }^{1} *$ and Mojahidul Islam ${ }^{2}$ \\ ${ }^{1 \& 2}$ Sociology Discipline, Khulna University, Khulna-9208, Bangladesh. \\ *Correspondence: jahidsoc14ku@gmail.com (Md. Jahidul Islam, Sociology Discipline, Khulna University, Khulna-9208, \\ Bangladesh).
}

\begin{abstract}
Early marriage is one of the major social problems in Bangladesh. Poverty has been the major factor leading to early marriage in Bangladesh. However, this study was an attempt to investigate the determinants affecting early marriage. The study is explanatory in nature as it tries to explain the determinants that affect the early marriage in the Khulna district of Bangladesh. The study was carried out in two areas, i.e, Paikgacha Village under Paikgacha Upzilla and 23 No. ward of Khulna city. The study adopted a survey research design. The population targeted by the study included only female respondents of 18 ages or above age group. 287 respondents were selected through a simple random sampling procedure using an interview schedule as survey research for data assortment. The major finding of the revision was that most of the respondents $(64.5 \%)$ were married and got at an early age. Results revealed that the majority of the respondents were affected by socioeconomic factors as for their early marriages. The study, however, identified association of premature marriage of the respondents with socio-cultural factors $(\mathrm{p}<.001)$, economic factors $(\mathrm{p}<.005)$, areas of residence $(\mathrm{p}<.001)$ at a strong significant level. So the study concluded that early marriage is affected by different sociodemographic factors such as parental education and income, parental early marriage, husband education, and income, area of residence.
\end{abstract}

Keywords: Early marriage, Parental, Socio-economic, Residence, Income, Education and Social status.

\section{INTRODUCTION:}

Around the world, marriage is considered a moment of celebration and a milestone in life. Actually, marriage is a universal social institution (United Nations, 1999). Through which an adult male and an adult female generally involve in a socially accepted relationship and acquire a new social status as husband and wife. But, sometimes, such an important social institution brings numerous problems for a couple, especially for the girl's woman, when it happens at an early age (Nasrin \& Rahman, 2012). UNICEF declared that marriage before 18 years of age is a reality for more than 60 million girls. Adolescent marriage (AM) re- mains quite prevalent in some parts of the developing countries, especially in South Asia, Western Asia, Sub-Saharan Africa and Latin America. It has been estimated that about 100 million teenagers would have been married before their $18^{\text {th }}$ birthday by 2013 (WHO, 2011; United Nation Fund for Population Activities, 2013). Pre-mature marriage deceptively denies a girls right towards health, education and a life free of violence (Singh \& Samara, 1996; Jensen \& Thornton, 2003). About $90 \%$ of the total population of Bangladesh is Muslim (Fleischer et al., 2010). However, the average age at first marriage for girls in Bangladesh is 18.7 years (BBS, 2009). Therefore, 
early marriage is seemingly a social norm in Bangladesh (Islam \& Mhamud, 1996) and it is specially practiced in poor families or in rural areas in the third world countries like Bangladesh. Although plenty of studies have been being declared that the female's age at first marriage in Bangladesh is still one of the lowest in the world, the situation remains spectacularly unchanged. In a study showed on 43 developing countries, the age at marriage of Bangladeshi girls was reported to be 14.1 years, the lowest amongst the studied countries (Singh \& Samara, 1996). Additionally, this study includes many case studies that show that early marriage rate is about 66 percent in Bangladesh and its position is $4^{\text {th }}$ in the world (BBS, 2011).

Interestingly, early marriage is more common for females than their male complements. In rural Bangladesh, there are many social compressions on the parents to marry their pubescent girls off (Aziz \& Maloney, 1985). The premature nuptial of young and adolescent girls as persists across countries is caused mainly by poverty, ignorance, social and cultural norms, societal conflicts and wars. The father in-law or husband to the daughter is well accepted most especially for their wealth and riches as they are expected to provide for the daughter and the daughter's family (UNDP, 2013). Families' distress from poverty often wants to reduce their number of children. As an approach, they marry off their daughters. Some families believe that it brings blessings to their family if they marry off girls before their puberty (Tristam, 2014). Now and again young girls 'expression less interest to carry on their education and in some cases, poor families are inept to bear the cost of education (Verma et al., 2013). Poverty is one of the major factors under-pining early marriages. Where poverty is acute, a young teenager may be regarded as an economic burden and the parents look for pre-mature marriage for their daughters as an alternative way of reducing the burden where one less daughter is one less mouth to feed (Mathur, 2003; Nour, 2006). This research further exposed that social cultural and religious factors are responsible for the first marriage (Barnes et al., 1998). On the other hand, for many societies that lead virginity before marriage, early marriage can visible it in a number of performs designed to protect a girl from illegal sexual activity.
Some parents withdraw their girls from school as soon as they begin to menstruate; fearing that exposure to male pupils or teachers puts them at risk (Amin, 2008).

Another study shows that, in Bangladesh, early marriage is one of the major social problems and it is the reason for girls' dropout of school. It is mainly related to the cultural background or custom (Shahidul, 2012). Moreover, There is a strong relation between higher age at marriage and higher education levels. In a study conducted by (Raj et al., 2010; Santhya et al., 2011) indicate that early marriage is associated with a range of adverse sexual and reproductive health outcomes for young girls and poor health outcomes for the children they bear. Besides, Studies in a number of south Asian countries, including Bangladesh, India and Nepal, show a direct association between early marriage and unintended pregnancy. Given the context, this study tried to find out the socioeconomic determinants of affecting the first marriage and the changes in the effects of these factors over time in Khulna district of Bangladesh.

\section{MATERIALS AND METHODS:}

The existent study is quantitative and explanatory in nature as it attempts to explain the relation between women's early marriage and its covariates. The study was approved by in two areas, i.e., Paikgacha Village under Paikgacha Upzilla and 23 No. ward of Khulna city. The study adopted survey research design approach. A total of 287 (out of 1144) women. We used to sample size calculation procedure revealed and applied simple random sampling to select the participants from the population where every single had an equal possibility of being selected. A semi-structured interviews Schedule having both open-ended and close-ended questions was developed and used as the main tool for attaining data from the respondents. The interviews Schedule were developed in English primarily to collect the data from the field. After developing the interviews Schedule, a pre-test of the interviews Schedule was conducted on 30 respondents, before the actual study, in order to find out anomalies. After necessary corrections, the final data collection process began. The data collection continued from the month of January to February, 2018 following group administration and short briefings to the participants. Once 
collected, the data were processed by SPSS and analyzed for further interpretation. We used both descriptive and inferential statistics to discuss potential factors that affected early marriage among the participants in this study. The descriptive statistics contain percentage analysis while inferential statistics was used to test association through Pearson's Chi-square test and Multiple Linear Regression modeling. The main outcome variable, determinants marriage was categorized as i.e. early marriage (below the 17 years) and late marriage (18 and above years) in this study.

\section{Variable list for the study}

\begin{tabular}{clll}
\hline Serial No. & Variable name & Variable description & Unit of Measurement \\
\hline $\mathbf{1 .}$ & Residence & Residence & Dummy(1= Urban, 2= Rural) \\
\hline $\mathbf{2 .}$ & Income & Income of the Household & Thousand taka/Month \\
$\mathbf{3 .}$ & Parent's education & Numeric & Numeric \\
\hline $\mathbf{4 .}$ & Education & Education of the respondent & Year of the schooling \\
$\mathbf{5 .}$ & Husband's Income & Husband's Income & Thousand taka/Month \\
\hline $\mathbf{6 .}$ & Husband's Education & Husband's Education & Year of the schooling \\
\hline $\mathbf{7 .}$ & Age at marriage & Age at marriage & Year \\
\hline
\end{tabular}

\section{RESULTS:}

Table 1 shows the demographic and socioeconomic characteristics of the respondents. It is found that the majority $(64.5 \%)$ of the participants got married at the age of below 17 or 17 years. whereas, (35.5\%) respondents got married at the stage of 18 years or above. In this study revealed that most of the respondents $(35.2 \%)$ were attained primary level of education whereas followed by secondary education (34.1\%). The percentage of the respondents having higher education is as low as (12.2\%). In this study (47.7\%) of the respondent's husband were attained higher education and income level of $37.3 \%$ respondent's family income was 10001-20000 per month from all sources. The data indicate that $76.7 \%$ respondent's mother got age at marriage Early and $(38.7 \%)$ of the respondent's mother were attained primary level. This study noted that $(86.1 \%)$ respondent's father got age at marriage within 21 years. Besides around partial of the participants $(50.9 \%)$ were belonged to urban area and $(49.1 \%)$ percent were rural area belonged to urban area. Moreover, around more than partial of the (61.3\%) respondents have their monthly household incomes between 3000-15000 Taka and rest of the (38.6\%) respondent's household income 30000 and above.

Table 1: Demographic and socio-economic information of the respondents

\begin{tabular}{cccc}
\hline Age at Marriage respondent year) & & Frequency & Percent \\
\hline & $\leq 17$ & 185 & 64.5 \\
& $\geq 18$ & 102 & 35.5 \\
\hline Respondent's Education & & & \\
\hline Husband's Education & Illiterate & 53 & 18.5 \\
& Primary & 101 & 35.2 \\
& Secondary & 98 & 34.1 \\
& Higher & 35 & 12.2 \\
\hline & & & 6.3 \\
& Illiterate & 18 & 12.2 \\
& Primary & 35 & 33.8 \\
& Secondary & 97 & 47.7 \\
\hline Husband Income & Higher & 137 & \\
\hline & & & 37.3
\end{tabular}




\begin{tabular}{cccc} 
& $12000-20000$ & 106 & 36.9 \\
& $\geq 20000$ & 74 & 25.8 \\
\hline Mother age at marriage & Early & 220 & 76.7 \\
& Late & 67 & 23.3 \\
\hline Mother's education & illiterate & 77 & 26.8 \\
& primary (1-5) & 111 & 38.7 \\
& Secondary(6-10) & 81 & 28.2 \\
& Higher & 18 & 6.3 \\
\hline Father Age at marriage & $\leq 20$ & & \\
\hline & $\geq 21$ & 40 & 86.1 \\
\hline Residence & Urban & & \\
\hline & Rural & 146 & 49.9 \\
\hline Household( Father) Income & & 141 & 61.3 \\
\hline & $3000-15000$ & 176 & 36.2 \\
\hline & $15000-30000$ & 104 & 2.4 \\
\hline
\end{tabular}

Source: Authors' compilation, 2018

\section{Bivariate analysis}

Table 2: Information about socio-economic determinants affecting the early marriage

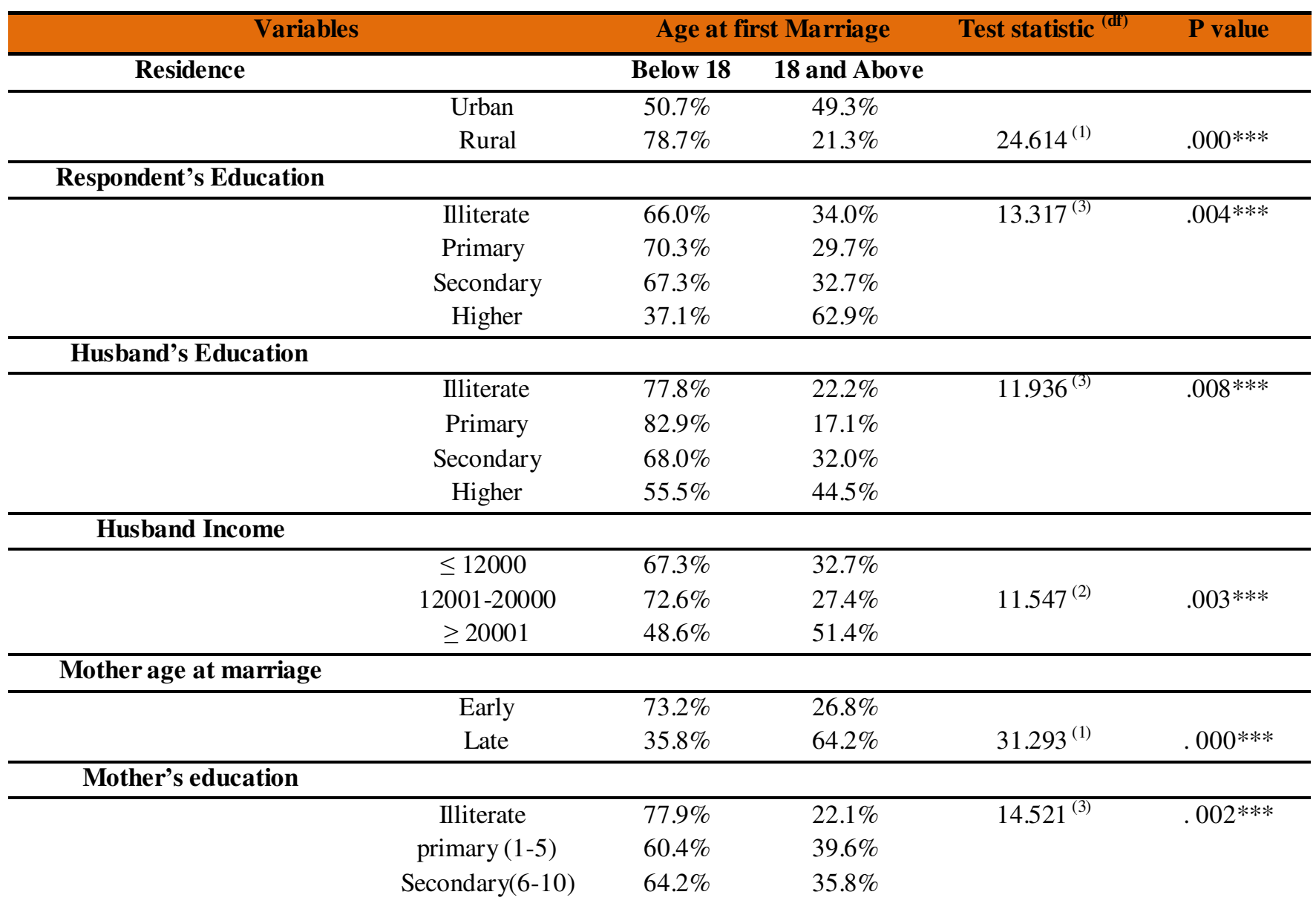

UniversePG I $\underline{\text { www.universepg.com }}$ 


\begin{tabular}{|c|c|c|c|c|c|}
\hline & Higher & $33.3 \%$ & $66.7 \%$ & & \\
\hline \multicolumn{6}{|l|}{ Father Age at marriage } \\
\hline & Early & $82.5 \%$ & $17.5 \%$ & $6.603^{(1)}$ & $.010 * *$ \\
\hline & Late & $61.5 \%$ & $38.5 \%$ & & \\
\hline \multicolumn{6}{|l|}{ Household ( Father) Income } \\
\hline & $\leq 15000$ & $64.2 \%$ & $35.8 \%$ & $12.356^{(2)}$ & $.005 * *$ \\
\hline & $15001-30000$ & $68.3 \%$ & $31.7 \%$ & & \\
\hline & $\geq 30001$ & $14.3 \%$ & $85.7 \%$ & & \\
\hline
\end{tabular}

Source: Authors' compilation, 2018

The result reported in Table 2 reveals the sociodemographic features of the respondents and their impact on the age of first marriage. The results of chisquare tests clarifies that respondents' residence, educational status, mother's age during her marriage, father's age during his marriage mother's educational status, husband's income and household income were significantly associated with their marital age. Alongside, we found that there is a statistically significant relationship between the residence of the origin as well as Mother's age at marriage and the age at first marriage of the respondents $(\mathrm{P}<.001)$. Similarly, Mother's education plays a vital role in the early marriage of their daughters. Mother with lower level of education have a greater inclination to the early marriage of their daughters and the association between different levels of mother's education and the age at first marriage of their daughters are statistically significant $(\mathrm{p}<.05)$.

\section{OLS predicting early marriage}

Table 3: OLS predicting early marriage

\begin{tabular}{cc}
\hline Independent Variable & Dependent Variable: Age At First Marriage \\
\hline (Constant) & $\boldsymbol{\beta}$ (S.E.) \\
\hline Age & $-.081(.239)$ \\
\hline Age of the husband & $-.170(.061)$ \\
Age at Marriage of Husband & $.531 *(.000)$ \\
Position among the siblings & $.266 *(.002)$ \\
Father's age during his marriage & $.229 *(.010)$ \\
Mother's age during her marriage & $.188 *(.042)$ \\
Respondent's Monthly income & $.293 *(.002)$ \\
Residence of the origin & $.260 * *(.000)$
\end{tabular}

Source: Authors' compilation, 2018

Regression is a broad class of statistical tools though in common usage that shows how one variable influence other variable linearly. In the study respondent's age at marriage is influenced by Age, residence of the origin, Age of husband, Husband age at marriage, respondent's position among the siblings, parent's age during their marriage and respondent's monthly income. This

Table 3 shows that Husband age at first marriage, respondent's position among the siblings, respondent's monthly income, and father's age during his marriage, respondents' residence of the origin and mother's age during her marriage had positive relation with early marital of the respondents, with regression coefficients $.531, .266, .293, .229, .260$ and .188 respectively, while participant's husband age and age of the respondents had negative relation with early marriage of the respondents with regression coefficients -.081 and -.170 respectively.

The factors of respondent's age (.239) and respondent's husband's age (.061) were at significant at one percent level. So in this regard it can be said that respondent's early marriage is influenced by resident, respondent's income, position of the participant and parent's age during marriage. 


\section{Predictors of early marriage among ever married women}

Table 4: Predictors of early marriage among ever married women

\begin{tabular}{lllll}
\hline Variables & \multicolumn{2}{l}{ Type of Marriage } & p value & \multirow{2}{*}{ AOR* (95\% C.I) } \\
\cline { 2 - 3 } Early & \multicolumn{2}{l}{ Late } & & \\
\hline Residence & & & & \\
\hline Urban & $50.7 \%$ & $49.3 \%$ & .00 & $2.81(1.55,5.08)$ \\
Rural & $78.7 \%$ & $21.3 \%$ & - & 1 \\
\hline Mother age at marriage & & & & \\
\hline Early & $73.2 \%$ & $26.8 \%$ & 0.00 & $0.18(0.09,0.36)$ \\
Late & $35.8 \%$ & $64.2 \%$ & - & 1 \\
\hline Respondent's Education & & & & \\
\hline Illiterate & $66.0 \%$ & $34.0 \%$ & - & 1 \\
Primary & $70.3 \%$ & $29.7 \%$ & 0.21 & $0.60(.27,1.343)$ \\
Secondary & $67.3 \%$ & $32.7 \%$ & 0.28 & $0.65(0.29,1.42)$ \\
Higher & $37.1 \%$ & $62.9 \%$ & 0.01 & $3.66(1.29,10.34)$ \\
\hline Religious factors & & & \\
\hline Yes & $60.5 \%$ & $39.5 \%$ & 0.01 & $2.29(1.19,4.42)$ \\
No & $72.8 \%$ & $27.2 \%$ & - & 1 \\
\hline Mother's education & & & \\
\hline Illiterate & $77.4 \%$ & $22.6 \%$ & 0.21 & $0.43(0.11,1.61)$ \\
primary (1-5) & $60.2 \%$ & $39.8 \%$ & 0.28 & $0.50(0.14,1.76)$ \\
Secondary(6-10) & $63.6 \%$ & $36.4 \%$ & 0.03 & $0.24(0.06,0.90)$ \\
Higher & $33.3 \%$ & $66.7 \%$ & - & 1 \\
\hline
\end{tabular}

Source: Authors' compilation, 2018

Results from binomial logistic regression represents the socio-demographic predictors of marital age of the participants in Khulna distract of Bangladesh. It appears that the odds for late marriage among urban women were 2.81 in comparison to rural women which elicits that early marriage inclination among urban was much higher than the rural. Here, the odds for late marriage among women whose mother had premature marriage were $18 \%$ indicating a very low incidence of late marriage among women whose mother had early marriage. Alongside, respondent's educational status was similarly analyzed where odds for late marriage among primary, secondary and higher were $66 \%, 65 \%$ and $3.66 \%$ respectively in comparison to the respondents whose educational was status low or who had no education.

Besides respondent's educational qualification, mother's education of the respondents was another potential predictor in influential the marital age of the participants as the results demonstration that the odds for late marriage among women whose mother's educational level fell into the illiterate and primary level UniversePG I www.universepg.com was only $1 \%$ for both educational levels in comparison to women whose mother's educational level fell into the higher. The odds for late marriage among the women who believed that religious factors were responsible for age at marriage was $1 \%$ in comparison to women who (Yasmin and Husna, 2020). Moreover, the odds for late marriage among those whose mother's had no education and only completed primary education was $43 \%$ and $50 \%$ respectively in comparison to women whose mother's had higher education in this study.

\section{DISCUSSION:}

The pattern of marriage (age at marriage, customs, rituals etc.) varies from one culture and society to another. Marriage pattern in South Asia reflects its societal and cultural context which affects the marital age in Bangladesh, where age at marriage is very early (Caldwell, 2005). More recently, UNICEF (2014) stated that Bangladesh has the fourth-highest rate of youth marital in the world. Hence, this revision was designed to explore the factors that determine early marriage among the women (Weerakoon, 2020). 
Findings of the study expose that the majority of respondents 51.9 percent belonged to age group 18-27 years which five of every ten who were get married before age of 18 years. In line with this findings, (UNICEF, 2015) found in its study that majority of women 20-24 years old were married or in union before age 18 years. The results of this study present that the majority of the participants (64.5 percent) got married at an early age (below 18 years) which is alarming and it is consistent with previous studies (Barkat \& Majid, 2003; UNICEF, 2014) that revealed most of the women were married under age 15 . Findings of the study present that the majority of the respondents receive the primary and secondary level of education. This outcome is also consistent of (Shahidul, 2012) early marriage is the major causes for stopping the girl's education. In this study, the highest of the respondents' mother (73.6 percent) faced premature marriage because of family pressure and it was consistent with the result of a previous study (UNIFPA, 2006) explained that parents may genuinely feel that their daughter will be better off and safer with a regular male guardian. Most of the respondents' faced early marriage for poverty and family honor and it is consistent with some previous studies (UNICEF, 2001; Mathur, 2003) which revealed that a young girl may be regarded as an economic burden and parents therefore look for early marriage of their daughters.

In this study the residences of the respondents were meaningfully connected with their early marital and it is consistent with the findings of previous studies (Hoq, 2011) that revealed women of rural areas have more tendency towards early marriage than those of urban areas because of their decision is not accepted by their parents. But it is inconsistent with the result of many other studies where the researchers revealed that Muslim women had higher tendency rate of early marriage than other religion (Tsujita, 2009; Jisun, 2012). On the other hand, Parent's early marriage cultures were significantly related with the respondent's early marriage in this study. It has a great impact on child's age at marriage influence. In this study it is seen that when parent's early marriage level is high then children's early marriage level must be high. But it is not found any others studies where the researchers is not exposed this factor. Year of schooling of the participant was also significantly linked UniversePG I www.universepg.com with early nuptial which is similar with the findings (Bates 2007; Field \& Ambrus, 2008) that indi-cated that women belonged to illiterate and primary level of education have highest tendency of early marriage than that of highly educated women. The present study did not found any positive relation bet-ween respondent's husband age and age at first marri-age. But another study found that husband's age was connected with early marriage (Shryock \& Siegel, 1976).

Findings depict that there was a significant relation between early marriage among the women and their mother's year of schooling and it is consistent with the findings of previous study (Nasrin \& Rahman, 2012) that also shows that Mothers with lower level of education have a higher tendency to the early marital of their daughters. On the other hand, age was not significantly associated with respondent's early marriage in this study. But it is inconsistent with the effects of other study where the researchers exposed that women of age group 20-25 have higher tendency towards early marriage which is statistically proved (Unger, 2013). Husband's years of schooling were significantly associated to early marriages among the respondents. In this study it is seen that where the husband's educational level is high then early marriage tendency must be low which is consistent with the result of other study (Nasrin \& Rhamna, 2012) that also found the case of husband's education of the respondents, where the illiterate husbands willingly marry a girl with an early age than those have different levels of higher education.

Statistics also reveal that monthly household income is expressively associated with early marriage. Previous studies also approved that early marriage is also very much affected by the family's monthly income and these studies showed that people from economically disadvantaged families tended to marry earlier as compared to those from advanced families (South \& Crowder, 2000; Synder et al., 2004). This study depict that there was a significant relation between husband's monthly income and early marriage. This result is consistent with another study which showed that a woman whose husband's income level is high then early marriage likely to must be low than those husbands's income is lower and medium (Axinn \& Thornton, 1992). Conclusions from findings reveal 
that, various determinants such as respondents' residence, year of schooling, husband's year of schooling and monthly income, mother's early marriage, father's early marriage, mother's year of schooling and respondent's income were knowingly linked with early marriage. On the contrary, there is no significant relationship among respondents religion, number of siblings and type of family, age of respondent and respondents husband age (Islam, 2020).

\section{CONCLUSION:}

Early marriage is an alarming matter through the world and remains a widespread problem particularly in the developing countries including Bangladesh. Early marital is still more extensive in the rural areas of Bangladesh. Bangladesh has laws to regulate initial marriage, but these laws are not followed by most of the people in our country. The findings of the contemporary study depicted that some factors affect the early marriage is related with health among the women. The study reveals that most of the women who got married at early age, did not give their decision at marriage since of low income family, poverty, respondent's education, mother's early marriage and father's age at marriage, parents education, husband's income and so on. In the rural area most of the participants were dropped out from school at primary and secondary level because were regarded as the economic burden in their family. Even the respondents had forced sexual union by their husbands and they were silently practicing traditional behavior regarding their reproductive issues. On the other hand the early marriage tendency is low in the urban areas of Khulna district. Women's health and education has improved during the past few years. But health status of women in the rural area is as improved as their demand (Shaikh et al., 2021). However, the government, child work activists, policy-makers, and social workers, civil societies should come forward to prevent the adolescents from the adverse effect of child marriage in Bangladesh.

\section{ACKNOWLEDGEMENT:}

The researcher greatly obliged for his Supervisor, Shaharior Rahman Razu, Assistant Professor, Sociology Discipline, Khulna University for his kind supervision, intellectual motivation, valuable advice and continuous guidance. The researcher would not be able to accomplish this paper without his careful readings of many drafts, rapid and practical feedback, and guidance that he provided. Alongside, the researcher also grateful to all his teachers of sociology discipline who have supported his by their advices and guidance many times in his study period.

\section{CONFLICTS OF INTEREST:}

The researcher declares no possible conflict of interest concerning the study, data collection \& analysis, authorship, and/or publication of this present article.

\section{REFERENCES:}

1) Amin, S., (2008). Reforming marriage practices in Bangladesh, Population council. Journal of Biosocial Science, 7(2), 1-20. https://doi.org/10.31899/pgy12.1042

2) Axinn, W. G., \& Thornton, A., (1992). The influence of parental resources on the timing of the transition to marriage. Social Science Res-earch, 21(4), 261-85.

3) Aziz, K., \& Maloney, C., (1985). Life stages, gender and fertility in Bangladesh, International Centre for Diarrhoeal Disease Research, Dhaka. http://dspace.icddrb.org/jspui/bitstream/123456789 /2564/1/Life

4) Bangladesh Bureau of Statistics (BBS), (2009). Statistical pocket book of Bangladesh. Ministry of planning, government of the people's republic of Bangladesh, Dhaka: Statistics Division.

5) Bangladesh Bureau of Statistics (BBS), (2011). Statistical pocket book of Bangladesh. Ministry of planning, government of the people's republic of Bangladesh, Dhaka: Statistics Division. http://203.112.218.65:8008/WebTestApplication/u serfiles/Image/LatestReports/YB2011.pdf

6) Barkat, A., \& Majid, M., (2003). Adolescent reproductive health in Bangladesh: Status, policies, programs and issues. Journal of Marriage and Family, 41(2), 887-891.

7) Barnes, I., Mushati, P., Hallett, T., \& Nyamukapa, C., (1998). Measuring trends in age at first sex and age at marriage in Manicaland. $J$. of social science, 3, 642-644.

https://pubmed.ncbi.nlm.nih.gov/19307339/ 
8) Bates, L., Joanna, M., \& Schuler, R. S., (2007). Women's education and the timing of marriage and childbearing in the next generation. Evidence from rural Bangladesh: Studies in Family Planning, 38(2), 101-112.

https://doi.org/10.1111/j.1728-4465.2007.00121.x

9) Caldwell, B. K. (2005). Factors affecting female age at marriage in South Asia: Contrasts between Sri Lanka and Bangladesh. Asian Population Studies, 1(3), 248-265.

10) Field, E., \& Ambrus, A., (2008). Early marriage age of menarche and female schooling. Journal of Political Economy, 116(5), 881-930.

https://www.journals.uchicago.edu/doi/abs/10.108 $\underline{6 / 593333}$

11) Fleischer, A., LutzJean, M., \& Schmidt, O., (2010). Population dynamics in Bangladesh: A case study on the causes and effects of demographic change in Bangladesh. World Journal of Social Sciences, 6(2), $51-61$.

12) Hoq, N. M., (2011). Regional differentials of age at first marriage among women in Bangladesh. Asian J. of Applied Science and Engineering, 2(2), 76-83.

http://publicationslist.org/data/ajase/ref-48/45 6 Template.pdf

13) Islam MJ., (2020). Factors influencing family size: a critical study on Khulna district of Bangladesh, Br. J. Arts Humanit., 2(4), 73-81. https://doi.org/10.34104/bjah.020073081

14) Islam, M., \& Mhamud, M., (1996). Marriage pattern and some issues related to adolescent marriage in Bangladesh. Asia-Pacific Population Journal, 11(3), 27-42.

15) Jisun, T. F., (2012). Early marriage of women: The case of Bangladesh. World Journal of Social Sciences, 6(2), 51- 61. https://zantworldpress.com/wp-content/uploads/ 2020/01/5.-Jisun.pdf

16) Mathur, M., (2003). Too young to wed: The lives, rights, and health of young married girls. Washington, D.C: International Center for Research on Women (ICRW).

17) Nasrin, S. O., \& Rahman, K. M., (2012). Factors affecting early marriage and early conception ofwomen: A case of slum areas in Rajshahi City,
Bangladesh. International Journal of Sociology and Anthropology, 4(2), 54-62. https://doi.org/10.5897/IJSA11.145

18) Nour, N., (2006). Health consequences of child marriage in Africa. J. of Emergency Infectious Diseases, 12(11), 1644-49.

19) Raj, A. B., Edwin, V., Glyn, C., \& Amudha p, R., (2010). Factors associated with teenage pregnancy in South Asia: a systematic review. Health Science Journal, 4(1), 3-14.

https://staffprofiles.bournemouth.ac.uk/display/jour nal-article/13130

20) Santhya, K., Acharya, R., Jejeebhoy, S., \& Ram, U., (2011). Timing of first sex before marriage and its correlates: evidence from India. Journal of Comparative Family Studies, 13(5), 327-341.

21) Shahidul, M., (2012). Marriage market and an effect on girls' school dropout in Bangladesh. Journal of Alternative Perspectives in the Social Sciences, 4(2), 552-564.

https://journal.vpweb.com/upload/7.\%20marriage \%20market.pdf

22) Shaikh MAK, Ahmed MK, and Haque R. (2021). Consequences of maternal mortality in Bangladesh rural families an experience of Gonoshasthaya Kendra (GK) 2008-2018, Br. J. Arts Humanit., 3(2), 22-47. https://doi.org/10.34104/bjah.021022047

23) Shryock, H. S., \& Siegel, J. S., (1976). The methods and materials of demography. Journal of Marriage and the Family, 45(3), 553-565.

24) Singh, S., \& Samara, R., (1996). Early marriage among women in developing countries', International Family Planning Perspectives. Asian J. of Applied Science and Engineering, 22(4), 148$157 \& 175$.

https://www.guttmacher.org/sites/default/files/pdfs /pubs/journals/2214896.pdf

25) South, S., \& Crowder, D., (2000). The declining significance of neighborhoods: Marital transitions in community context. Journal of Social and anthropology, 78(3), 067-1099.

26) Synder , A., Brown , S., \& Condo , E., (2004). Residential differences in family formation: The significances of cohabitation. Rural Sociol. J.of Public Health Epidemiol, 69(2), 255-260. https://doi.org/10.1526/003601104323087598 
27) Thornton, R., \& Jensen, R., (2003). Early female marriage in the developing world. Journal of Gender and Development, 11(2), 9-19. https://doi.org/10.1080/741954311

28) Tristam, P., (2014). Child marriage: Facts, causes and consequences. World J. of Social Sci., 22(1), 35-59.

29) Tsujita, Y., (2009). A study of slum children in Delhi, India. Deprivation of Education, Education for All Global Monitoring Report 2010. http://ddpext.worldbank.org/EdStats/INDgmrpap09b.pdf

30) UNDP, (2013). The Rise of the South: Human progress in a diverse world. 1 UN Plaza, New York, NY 10017, USA: United Nations Development Programme (UNDP).

31) Unger, A., (2013). Children's health in slum settings. Global child health, Division of Hospital Medicine, University of California, San Francisco, Arch Dis Child. 98(10): 799-805. https://adc.bmj.com/content/98/10/799

32) UNICEF, (2001). Early marriage child spouses. Innocenti digest. Florence, Italy: J Women's Health Care.

33) UNICEF, (2014). Early marriage: A harmful traditional practice: A statistical exploration. N.Y, USA

http://www.unicef.org/publications/files/Early Ma rriage 12.lo.pdf

34) UNICEF, (2015). Progress for Children: A report card on adolescents. New York.

35) UNIFPA, (2006). In ending child marriage, A guide for global policy action International Planned Parenthood Federation and the Forum on Marriage and the Rights of Women and Girls. U.K.

36) United Nation Fund for Population Activities, (2013). State of world population 2013: motherhood in childhood. New York: UNFPA, Pp. 113. https://www.unfpa.org/publications/state-worldpopulation-2013

37) United Nations, (1999). Pattern of first marriage: Timing and prevalence. New York: Department of International Economic and Social Affairs.

38) United Nations International Childrens Emergency Fund, (2012). Early marriage: A harmful traditional practice: A statistical exploration. N.Y, USA.

https://resourcecentre.savethechildren.net/library/e arly-marriage-harmful-traditional-practice

39) Verma, R., Sinha, T., \& Khanna, T., (2013). Asia child marriage initiative: Summary of research in Bangladesh, India and Nepal. International j. Center for Res. on Women, 35-46.

40) Weerakoon T. (2020). Factors affecting diffusion of entitlement in consumption of scarce commodities: a psychological approach, $B r . J$. Arts Humanit., 2(6), 113-128. https://doi.org/10.34104/bjah.02001130128

41) World Health Organization, (WHO), (2011). Guidelines on preventing early pregnancies and poor reproductive: Outcomes among adolescents in developing countries. Geneva-New York.

42) Yasmin T., and Husna CA., (2020). Familial support as a determinant of women career development: a qualitative study, Asian J. Soc. Sci. Leg. Stud., 2(4), 76-87. https://doi.org/10.34104/ajssls.020.076087

Citation: Islam MJ and Islam M. (2021). Determinants of early marriage among the women: a study on Khulna district, Asian J. Soc. Sci. Leg. Stud., 3(3), 89-98. https://doi.org/10.34104/ajssls.021.089098 @ @ 